\title{
Kinerja Dokter Muda sebagai Mediasi Pengaruh Burnout, Kecerdasan Emosional, Self-efficacy terhadap Kepuasan Kerja di Rumah Sakit dr. Soetomo Surabaya, Indonesia
}

\author{
Raden Andi Sularso \\ Universitas Jember \\ Korespondensi penulis: manajemen1234@yahoo.com
}

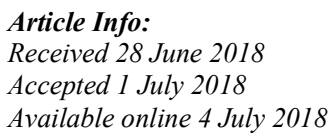

Abstract: Job satisfaction and performance of co-assistant doctors can not be separated by burnout, given the high mobility of work in clinical studies and assisting clinical lecturers in serving patients. Burnout is a psychological syndrome consisting of three dimensions, namely emotional exhaustion, depersonalization, and low personal accomplisment. To achieve the performance and job satisfaction of young physicians with intervening emotional intelligence and self-efficacy can anticipate burnout. This study includes the type of explanatory research with cross-sectional data collection method. The sample size is the same as the population of 270 co-assistants with the Generalized Structured Component Analysis (GSCA) method. The results of this study found that from seven direct effects between the variables tested, there are five significant effects that are: (1) burnout have a significant effect on emotional intelligence; (2) burnout have a significant effect on self-efficacy; (3) self-efficacy have a significant effect on emotional intelligence; (4) emotional intelligence has a significant effect on performance, and (5) self-efficacy has a significant effect on performance, while (1) burnout has no significant effect on self-efficacy; and (2) co-assistant performance has no significant effect on co-assistant doctor job satisfaction.

Keywords: Burnout, Emotional intelligence, Self-efficacy, Performance, Satisfaction, Co-assistant.

\section{LATAR BELAKANG}

Pendidikan profesi dokter pada mahasiswa program studi kedokteran atau disebut dengan ko-as (Co-assistant) dilakukan oleh mahasiswa setelah lulus dari sarjana kedokteran (S.Ked.). Mahasiswa yang melaksanakan program ko-as, proses pembelajaran dilakukan di rumah sakit pendidikan dan pelayanan kesehatan yang setingkat dengan rumah sakit pendidikan yang diberikan ijin oleh Kementerian Kesehatan. Pada tahap pendidikan ko-as, mahasiswa kedokteran mengaplikasikan teori, mengembangkan pengetahuan dan ketrampilan, perilaku, dan etika dalam melayani 
pasien. Setelah menyelesaikan dan lulus ko-as, mahasiswa harus mengikuti UKDI (Ujian Kompetensi Dokter Indonesia). Lulus dari UKDI, mahasiswa baru bisa menyandang gelar dokter.

Dalam proses pelayanan, termasuk pelayanan kesehatan tidak terlepas dari kemungkinan terjadinya kelelahan atau disebut dengan istilah burnout. Kehidupan dokter muda yang melaksanakan ko-as di rumah sakit dr. Soetomo Surabaya mengalami proses belajar dengan mengaplikasikan teori bersama dengan pekerjaan rutin melayani pasien, piket malam, dan mengerjakan tugas-tugas dari dosen, sehingga mereka tidak terlepas dari kondisi burnout. Burnout merupakan kelelahan emosional, depersonalisasi low personal accomplisment (Maslach \& Jackson, 1997), sedangkan menurut Lee dan Ashforth (dalam Alam, 2007) menyatakan bahwa burnout merupakan kondisi yang menekan, sehingga menimbulkan keputusasaan, kelelahan, dan keletihan. Salah satu cara mengatasi burnout adalah self-efficacy, seperti yang dinyatakan oleh Baron dan Byrne (1991) yang menyebutkan bahwa self-efficacy merupakan kemampuan atau kompetensi yang dimiliki seseorang untuk melakukan pekerjaan dan mengatasi hambatannya.

Penelitian Skaalvik dan Skaalvik (2010) dan Schaufeli dan Buunk (2007) menunjukkan bahwa self-efficacy berpengaruh positif dan signifikan terhadap burnout. Penelitian Maharani (2011) menunjukkan sebaliknya, yaitu self-efficacy berpengaruh signifikan terhadap burnout dengan arah negatif, apabila self-efficacy tinggi maka burnout akan rendah. Pervin dan John (1997) dalam teorinya menyatakan bahwa selfefficacy merupakan kemampuan dari unsur getaran pemikiran di dalam kecerdasan emosional. Kemampuan yang dimaksud tersebut, oleh Goleman (2002) disebut dengan kecerdasan emosional. Penelitian Ani (2010), Jorfi et al. (2010), dan Shahosseini et al. (2012) menyimpulkan bahwa kecerdasan emosional berpengaruh signifikan dengan arah positif terhadap kinerja. Penelitian Vivin (2013) menyatakan bahwa burnout dan kecerdasan emosional berpengaruh signifikan terhadap kinerja pegawai. Kemampuan kinerja dokter muda yang mengindikasikan kecerdasan emosional dilihat dari kemampuan mengelola diri sendiri dan kemampuan membina hubungan dengan orang lain (Alvis \& Siti, 2013).

Kepuasan kerja dan kinerja merupakan topik yang menarik, karena dampak dari korelasi kepuasan kerja dan kinerja dapat meningkatkan produktivitas. Keterbaruan pada penelitian ini adalah kinerja dokter muda berpengaruh terhadap kepuasan kerja mereka. Berdasarkan teori Gibson et al. (2010) menggambarkan adanya hubungan timbal balik antara kepuasan kerja dan kinerja.

\section{Tujuan Penelitian}

Tujuan dalam penelitian ini adalah untuk menganalisis dan menjelaskan: (1) pengaruh burnout terhadap kecerdasan emosional, (2) pengaruh burnout terhadap kinerja, (3) pengaruh burnout terhadap self-efficacy, (4) pengaruh self-efficacy terhadap kecerdasan emosional, (5) pengaruh kecerdasan emosional terhadap kinerja, (6) pengaruh self-efficacy terhadap kinerja, dan (7) pengaruh kinerja terhadap kepuasan kerja. 


\section{TINJAUAN TEORITIS}

Burnout merupakan suatu keadaan kelelahan atau kehabisan tenaga (Babakus, et al. 2009). Pines dan Guendlman (1995) menyatakan burnout merupakan seseorang yang mengalami kelelahan (depersonalization), karena tekanan pekerjaan terus menerus. Bhanugopan dan Alan (2006) mengatakan burnout adalah kondisi kelelahan kerja, mengalami kelelahan mental, kehilangan komitmen, kelelahan emosional, dan juga mengalami penurunan motivasi. Maslach dan Jackson (1981) mendiskripsikan burnout sebagai kondisi kelelahan emosional, depersonalization, dan personal accomplishment. Baron dan Greenberg (2008) mengatakan indikator dari burnout terdiri atas kelelahan fisik, kelelahan emosional, kelelahan mental, dan rendahnya penghargaan diri. Schaufeli dan Buunk (2003) dalam penelitiannya menyebutkan burnout berpengaruh terhadap self-efficacy.

Self-efficacy merupakan keyakinan seseorang untuk menghasilkan tingkat kinerja yang akan mempengaruhi kehidupannya (Bandura, 1997). Ivancevich et al. (2006) menjelaskan bahwa self-efficacy merupakan keyakinan pribadi terhadap kemampuan kompetensi. Namun, Lev dan Koslowsky (2009) menjelaskan bahwa self-efficacy merupakan kondisi fisiologis, subyektif pengaruh personal, sedangkan pengaruh lainnya terhadap self-efficacy, yaitu merasa takut, cemas, tegang, dan merasa kurang mampu untuk mengerjakan tugas yang diberikan. Penelitian Maharani (2011) menyebutkan selfefficacy berpengaruh signifikan dengan arah negatif terhadap burnout yang terjadi pada guru-guru di kota Bogor. Artinya, semakin tinggi self-efficacy yang dimiliki oleh guru, semakin rendah burnout yang dialaminya.Ddemikian pula sebaliknya, apabila selfefficacy yang dimiliki guru rendah, maka burnout yang dialami semakin tinggi.

Kecerdasan emosional merupakan kemampuan untuk merasakan dan memahami kepekaan emosi dan pengaruh yang manusiawi (Goleman, 2002), sehingga kecerdasan emosional sangat diperlukan untuk menghasilkan produktifitas yang tinggi dalam pekerjaan (Sam'ani, 2008). Orang yang memiliki kecerdasan emosional yang baik akan mampu menghadapi tantangan dan menjadikannya penuh tanggung jawab, produktif, dan optimis dalam menghadapi dan menyelesaikan masalah. Hal-hal tersebut sangat dibutuhkan dalam hubungan kerja. Menurut Patton (2011), kecerdasan emosional semakin tinggi cenderung semakin trampil melakukan apa yang dikerjakan.

Kinerja merupakan sebuah proses hubungan antara input dan output (Kaiser \& Ringstetter, 2011). Kinerja dokter muda akan sangat dipengaruhi oleh cara mereka merespon kondisi yang mempengaruhi proses kerjanya. Mathis dan Jackson (2009) menjelaskan kinerja merupakan apa yang dilakukan dan dikerjakan oleh karyawan yang meliputi hasil, kuantitas, kualitas, waktu, kehadiran, dan kemampuan bekerja sama. Hasil penelitian Imaniar dan Sularso (2016) menyimpulkan bahwa burnout berpengaruh signifikan dengan arah negatif terhadap kinerja dokter muda, sedangkan kecerdasan emosional berpengaruh signifikan terhadap kinerja, dan self-efficacy berpengaruh signifikan terhadap kinerja.

Setiap individu memiliki tingkat kepuasan kerja yang berbeda sesuai dengan sistem nilai yang berlaku pada dirinya. Semakin banyak aspek dalam pekerjaan yang sesuai dengan kepentingan dan harapan individu tersebut, maka akan semakin tinggi tingkat kepuasan yang dirasakannya, demikian pula sebaliknya. Luthans (2006: 243) mendifinisikan kepuasan kerja sebagai suatu keadaan emosi positif atau senang yang berasal dari penilaian pekerjaan atau pengalaman kerja. Oleh karena itu, kepuasan kerja mencerminkan perasaan seseorang terhadap pekerjaannya. Dampak dari korelasi 
kepuasan kerja dan kinerja dapat meningkatkan produktivitas (Smith, 2000). Levy (2003) mengatakan bahwa hasil kepuasan kerja mengarah pada kinerja yang baik dan perubahan perilaku.

\section{Hipotesis}

Hipotesis yang diajukan pada penelitian ini adalah: (1) burnout berpengaruh signifikan terhadap kecerdasan emosional; (2) burnout berpengaruh signifikan terhadap kinerja; (3) burnout berpengaruh signifikan terhadap self-efficacy; (4) self-efficacy berpengaruh signifikan terhadap kecerdasan emosional; (5) kecerdasan emosional berpengaruh signifikan terhadap kinerja; (6) self-efficacy berpengaruh signifikan terhadap kinerja; dan (7) kinerja berpengaruh signifikan terhadap kepuasan kerja.

\section{METODE PENELITIAN}

Populasi dalam penelitian adalah dokter muda yang melaksanakan ko-as (coassistant) di rumah sakit dr. Soetomo Surabaya, Indonesia sebanyak 270 orang. Pengambilan sampel dilakukan dengan metode sensus. Pengumpulan data dilakukan dengan cara: (1) survei dengan memberikan kuesioner (daftar pernyataan) kepada responden yang ditemui pada waktu melakukan ko-as di rumah sakit dr. Soetomo Surabaya, Indonesia; dan (2) wawancara yang dimaksudkan untuk mendapatkan informasi tambahan terkait permasalahan dalam memberikan layanan kepada pasien. Metode analisis data yang digunakan dalam studi ini adalah analisis diskripsi dan statistika inferensial, yaitu Generalized Structured Component Analysis (GSCA).

\section{HASIL PENELITIAN DAN PEMBAHASAN}

\section{Evaluasi Goodness-of-fit Model Structural dan Overall Model}

Model yang diuji dalam studi ini dikatakan fit apabila didukung oleh data empiris. GSCA memberikan ukuran goodness-of-fit yang terdiri atas fit model structural dan overall model yang dapat dilihat dari nilai FIT, AFIT, GFI (Unweighted least-squares) dan SRMR (Standardized root mean square residual). Hasil komputasi data dari studi ini dengan metode GSCA diperoleh model fit yang disajikan pada Tabel 1 berikut.

Tabel 1. Evaluasi Goodness of Fit Model Structural dan Overall Model GSCA

\begin{tabular}{|c|c|}
\hline \multicolumn{2}{|c|}{ Model Fit } \\
\hline FIT & 0.717 \\
\hline AFIT & 0.855 \\
\hline GFI & 0.993 \\
\hline SRMR & 0.176 \\
\hline NPAR & 52 \\
\hline
\end{tabular}

Sumber: Hasil analisis data, 2018.

Dari hasil output GSCA pada Tabel 1, evaluasi goodness-of-fit model structural dan overall model penelitian ini dapat diuraikan sebagai berikut: 
1. FIT merupakan varian total dari keseluruhan variabel yang dianalisis dan dapat dijelaskan oleh model penelitian ini. Hasil output GSCA diperoleh nilai FIT sebesar 0,717 yaitu model yang terbentuk dalam penelitian ini dapat menjelaskan semua variabel yang dianalisis sebesar $71,70 \%$. Keragaman variabel burnout, kecerdasan emosional, self-efficacy, dan kinerja dokter muda dapat dijelaskan oleh model sebesar $71,70 \%$ dan sisanya $28,30 \%$ dijelaskan oleh variabel lain di luar model penelitian. Dapat disimpulkan bahwa dari nilai FIT yang diperoleh model penelitian ini dapat dikatakan memiliki akurasi atau ketepatan model yang baik karena nilainya lebih besar dari $60 \%$.

2. AFIT sebesar 0,855 adalah adjusted dari FIT yang hampir sama dengan nilai FIT. Namun, karena variabel yang mempengaruhi kepuasan kerja dokter muda dalam penelitian ini tidak hanya satu melainkan empat variabel, yaitu: burnout, kecerdasan emosional, self-efficacy, dan kinerja dokter muda, sehingga akan lebih baik jika interpretasi ketepatan model menggunakan FIT yang sudah terkoreksi atau AFIT (Adjusted FIT). Karena banyaknya variabel yang mempengaruhi, maka nilai FIT akan semakin besar, karena proporsi keragaman meningkat, sehingga untuk menyesuaikan dengan variabel yang ada dapat menggunakan FIT yang sudah terkoreksi. Jika dilihat dari nilai AFIT, keragaman variabel burnout, kecerdasan emosional, self-efficacy, dan kinerja dokter muda dapat dijelaskan oleh model penelitian ini sebesar $85,50 \%$ dan sisanya $14,50 \%$ dijelaskan oleh variabel lain. Artinya, nilai AFIT yang diperoleh menunjukkan bahwa model yang terbentuk memiliki akurasi atau ketepatan model yang baik karena nilainya lebih besar dari $60 \%$.

3. GFI dan SRMR, keduanya sebanding dengan perbedaan antara kovarian sampel dan kovarian yang diproduksi oleh pendugaan parameter GSCA. Hasil analisis data terlihat nilai GFI sebesar $0,993 \geq$ cut-off poin 0,90 , maka model yang terbentuk dapat dikatakan sudah sesuai atau baik. Namun, nilai SRMR sebesar 0,176 > 0,1 dapat dikatakan poor fit (model tidak sesuai). Hal ini dimungkinkan terjadi pada penelitian ini, karena arah indikator pengukuran antara variabel yang belum diketahui secara pasti dan pengaruh kompleksitas model, tetapi masih dapat ditolerir karena nilai SRMR mendekati nol.

4. Nilai NPAR sebesar 52 menunjukkan bahwa jumlah parameter bebas yang termasuk koefisien loading (c), koefisien bobot (w), dan koefisien jalur (b) di dalam penelitian ini.

Berdasarkan goodness-of-fit model structural dan model keseluruhan (overall model) dengan uji FIT, AFIT, GFI, dan SRMR dapat disimpulkan bahwa kompleksitas model yang dispesifikasi dalam penelitian ini mampu menjelaskan $85,50 \%$ varian data yang telah terkoreksi. Begitu pula nilai $\mathrm{GFI}=0,993$ dan $\mathrm{SRMR}=0,176$ yang menunjukkan model fit yang baik (GFI $\geq 0,90$ dan SRMR mendekati nol).

\section{Pengujian Model Struktural dan Hipotesis Penelitian}

Model struktural dievaluasi dengan melihat nilai koefisien jalur hubungan antara variabel laten. Pengujian model struktural dilakukan setelah model hubungan yang dibangun sesuai dengan data hasil observasi dan kesesuaian model secara keseluruhan (goodness-of-fit model overall). Tujuan pengujian terhadap model hubungan struktural untuk mengetahui hubungan antara variabel laten yang dirancang dalam penelitian ini. Dari output model GSCA, pengujian model struktural dan hipotesis dilakukan dengan 
melihat nilai estimasi koefisien jalur dan nilai titik kritis $\left(\mathrm{CR}^{*}\right)$ yang signifikan pada $\alpha$ $=0,05$. Hasil analisis data secara lengkap dapat dilihat pada output model GSCA. Berdasarkan kerangka konseptual, maka hasil pengujian hubungan antara variabel berikut ini.

\section{Pengujian Hipotesis dan Koefisien Jalur Pengaruh Langsung}

Pengujian hipotesis dan koefisien jalur pengaruh langsung antara variabel burnout, kecerdasan emosional, self-efficacy, kinerja dokter muda, dan kepuasan kerja dokter muda. Hasil pengujian pengaruh langsung dapat dilihat dari nilai koefisien jalur dan titik kritis $\left(\mathrm{CR}^{*}\right)$ yang signifikan pada $\alpha=0,05$ disajikan pada diagram jalur pada Gambar 1 berikut.

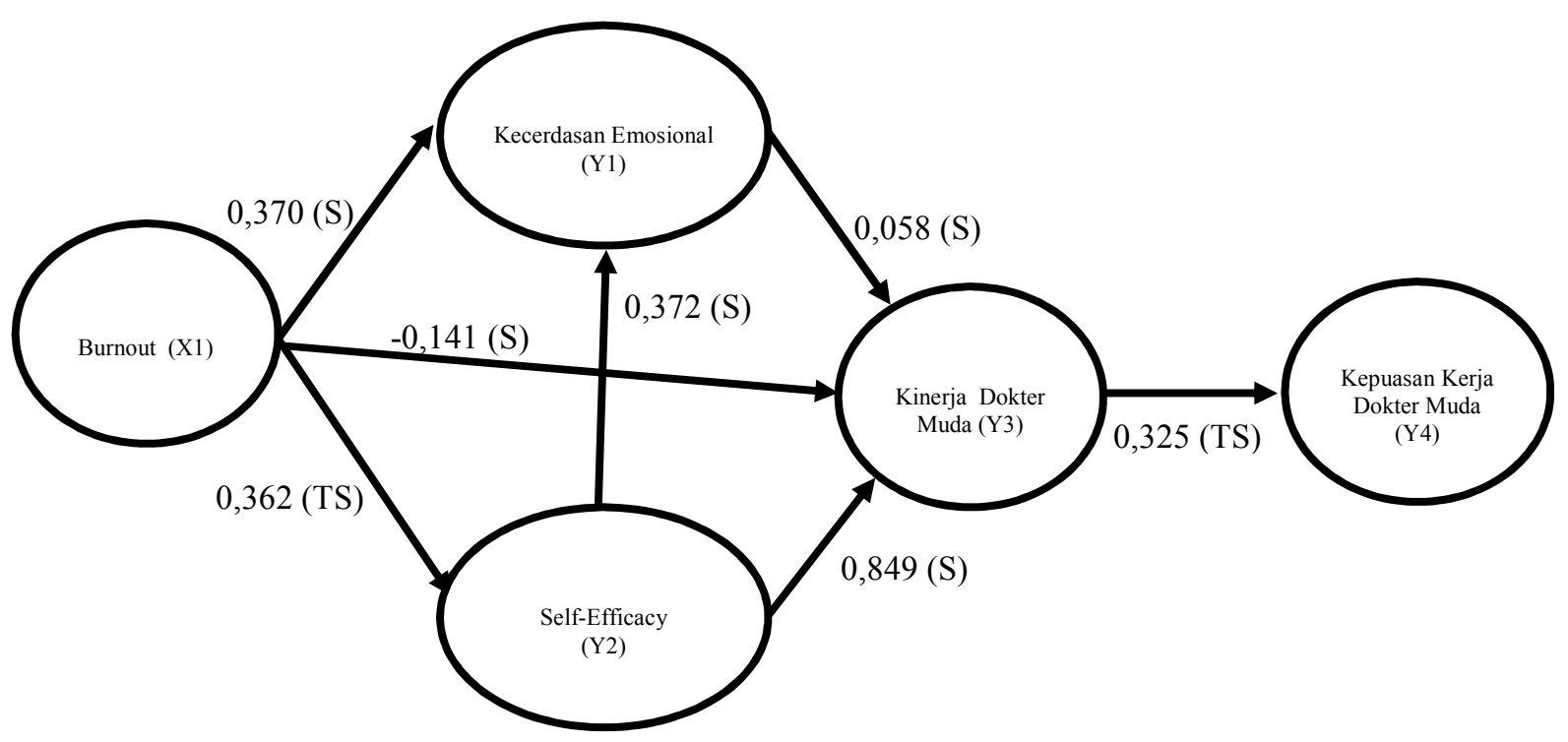

Gambar 1. Koefisien Jalur dan Pengujian Hipotesis

Hasil pengujian pada Gambar 1 terlihat bahwa dari tujuh pengaruh langsung antara variabel yang diuji terdapat lima variabel berpengaruh signifikan, yaitu: (1) variabel burnout berpengaruh signifikan terhadap kecerdasan emosional; (2) burnout berpengaruh signifikan terhadap self-efficacy; (3) self-efficacy berpengaruh signifikan terhadap kecerdasan emosional; (4) kecerdasan emosional berpengaruh signifikan terhadap kinerja, dan (5) self-efficacy berpengaruh signifikan terhadap kinerja dokter muda. Namun, dua variabel berpengaruh tidak signifikan, yaitu: (1) variabel burnout berpengaruh tidak signifikan terhadap self-efficacy; dan (2) kinerja dokter muda berpengaruh tidak signifikan terhadap kepuasan kerja dokter muda. Hasil pengujian pengaruh langsung antarvariabel pada penelitian ini secara lengkap dapat disajikan pada Tabel 2. 
Tabel 2. Koefisien Jalur Pengaruh Langsung dan Hasil Pengujian Hipotesis

\begin{tabular}{clcccc}
\hline Hipotesis & \multicolumn{1}{c}{ Pengaruh Langsung } & $\begin{array}{c}\text { Koefisien } \\
\text { Jalur }\end{array}$ & C.R & Sig. & Keterangan \\
\hline $\mathrm{H}_{1}$ & $\begin{array}{l}\text { burnout } \rightarrow \text { kecerdasan } \\
\text { emosional }\end{array}$ & 0.370 & $2.16^{*}$ & Signifikan & Diterima \\
\hline $\mathrm{H}_{2}$ & $\begin{array}{l}\text { burnout } \rightarrow \text { kinerja dokter } \\
\text { muda }\end{array}$ & -0.141 & 2.98 & Signifikan & Diterima \\
\hline $\mathrm{H}_{3} \quad$ burnout $\rightarrow$ self-efficacy & 0.362 & $1.7^{*}$ & Tidak signifikan & Ditolak \\
\hline $\mathrm{H}_{4} \quad \begin{array}{l}\text { self-efficacy } \rightarrow \text { kecerdasan } \\
\text { emosional }\end{array}$ & 0.372 & $4.38^{*}$ & Signifikan & Diterima \\
\hline $\mathrm{H}_{5} \quad \begin{array}{l}\text { kecerdasan emosional } \rightarrow \\
\text { kinerja dokter muda }\end{array}$ & 0.058 & 2.96 & Signifikan & Diterima \\
\hline $\mathrm{H}_{6} \quad \begin{array}{l}\text { self-efficacy } \rightarrow \text { kinerja dokter } \\
\text { muda }\end{array}$ & 0.849 & $20.19^{*}$ & Signifikan & Diterima \\
\hline $\mathrm{H}_{7}$ & $\begin{array}{l}\text { kinerja dokter muda } \rightarrow \\
\text { kepuasan kerja dokter muda }\end{array}$ & 0.325 & 1.42 & Tidak signifikan & Ditolak \\
\hline $\begin{array}{l}\text { Keterangan: } \\
\mathrm{CR}^{*}=\text { signifikan di level .05 }\end{array}$ & & & & \\
\hline
\end{tabular}

Sumber: Hasil analisis diolah.

Berdasarkan hasil penelitian ini, maka pengujian pengaruh langsung dan hipotesis penelitian bertujuan untuk menjawab apakah hipotesis yang diajukan dapat diterima atau ditolak. Hasil pengujian hipotesis pengaruh langsung dapat dijelaskan sebagai berikut:

\section{$\mathrm{H}_{1}$ : Burnout berpengaruh signifikan terhadap kecerdasan emosional.}

Hasil pengujian pengaruh burnout terhadap kecerdasan emosional dapat dibuktikan dengan nilai estimate koefisien jalur sebesar 0,370 dengan arah positif. Koefisien jalur bertanda positif memiliki arti hubungan antara burnout dengan kecerdasan emosional adalah searah. Kemudian, dapat pula dibuktikan dengan nilai titik kritis (CR) sebesar $2,16^{*}$ dan signifikan pada $\alpha=0,05$. Hasil pengujian hipotesis $\left(\mathrm{H}_{1}\right)$ membuktikan bahwa burnout berpengaruh signifikan dan positif terhadap kecerdasan emosional. Artinya, peningkatan burnout searah dan nyata terhadap peningkatan kecerdasan emosional, sehingga hipotesis yang diajukan dalam penelitian ini dapat diterima atau didukung oleh realitas yang terjadi pada obyek dalam penelitian ini. Hal ini menunjukkan bahwa jika semakin tinggi tingkat burnout yang dimiliki dokter muda, maka akan semakin tinggi tingkat kecerdasan emosional dokter muda. Sebaliknya, jika burnout yang dimiliki oleh dokter muda semakin rendah, maka akan dapat mengakibatkan semakin rendah pula kecerdasan emosional dokter muda tersebut. Hal ini mengindikasikan bahwa burnout terbukti berpengaruh signifikan secara nyata, karena didukung fakta lapangan. Temuan ini sama dengan teori Banughopan (2006) mengenai para pekerja yang terkena burnout akan mengalami kelelahan mental, kelelahan emosional, kehilangan komitmen, dan mengalami penurunan motivasi diri seiring dengan berjalannya waktu. Temuan penelitian ini mendukung hasil penelitian sebelumnya yang telah dilakukan oleh Alam (2010); Devi (2011); Khanifar et al. (2012); Thomas et al. (2012); dan Idrus (2016). 


\section{$\mathrm{H}_{2}$ : Burnout berpengaruh signifikan terhadap kinerja dokter muda.}

Hasil pengujian menunjukkan bahwa nilai estimasi koefisien jalur pengaruh langsung burnout terhadap kinerja dokter muda sebesar -0,141 dengan nilai titik kritis (CR) sebesar 2,98 dan probabilitas ( $p$-value) lebih besar 0,05 berarti signifikan pada tingkat kepercayaan 95\%. Hasil pengujian menunjukkan bukti realitas yang terjadi, sehingga hipotesis $\left(\mathrm{H}_{2}\right)$ yang dinyatakan burnout berpengaruh signifikan terhadap kinerja dokter muda dapat diterima. Namun, dengan melihat tanda koefisien jalur negative, berarti hubungan antara burnout dengan kinerja dokter muda berlawanan arah. Hal tersebut menggambarkan semakin tinggi tingkat burnout yang dialami dokter muda, maka akan semakin rendah tingkat kinerja yang dihasilkan. Demikian pula sebaliknya, apabila tingkat burnout yang dialami dokter muda semakin rendah, maka semakin tinggi tingkat kinerja dokter muda yang dihasilkannya. Temuan ini mengkonfirmasi dan memperluas hasil penelitian sebelumnya yang dilakukan oleh Babakus et al. (2009); Ybema, Smulders, dan Bongers (2010); Gorji (2011); Gorji dan Vaziri (2011); Kounenou dan Demerouti (2012); Ybema, Smulders, dan Bongers (2010); dan Chen dan Kao (2012). Namun, penelitian ini berbeda dengan penelitian yang dilakukan oleh Idrus (2016) yang menyatakan bahwa burnout berpengaruh tidak signifikan terhadap kinerja pramuwisata di Provinsi Nusa Tenggara Barat.

\section{$\mathrm{H}_{3}$ : Burnout berpengaruh tidak signifikan terhadap self-efficacy.}

Hasil analisis pengaruh burnout terhadap self-efficacy diperoleh nilai estimasi koefisien jalur pengaruh langsung sebesar 0,362 dengan nilai titik kritis (CR) sebesar 1,7* dan signifikan $\alpha=0,05$ pada tingkat kepercayaan 95\%. Hasil ini menunjukkan ketidak cukupan bukti untuk menerima hipotesis $\left(\mathrm{H}_{3}\right)$ bahwa semakin baik burnout, maka semakin tidak baik self-efficacy. Mencermati nilai koefisien jalur bertanda positif dapat diartikan bahwa hubungan antara burnout dan self-efficacy adalah searah. Hubungan searah tersebut berarti burnout yang baik mampu meningkatkan self-efficacy, tetapi tidak signifikan. Hal ini mengindikasikan bahwa burnout secara nyata mempunyai peranan kurang penting terhadap self-efficacy, sehingga temuan penelitian ini berbeda dengan teori Baron dan Byrne (1991) tentang self-efficacy yang merupakan evaluasi seseorang mengenai kemampuan atau kompetensi dirinya untuk melakukan tugas, mencapai tujuan, dan mengatasi hambatan (burnout) yang dialaminya. Temuan ini berbeda dengan temuan penelitian yang telah dilakukan sebelumnya oleh Skaalvik dan Skaalvik (2010); Maharani (2011); Aftab et al. (2012); dan Idrus (2016).

\section{$\mathrm{H}_{4}$ : Self-efficacy berpengaruh signifikan pada kecerdasan emosional.}

Hasil pengujian diperoleh bahwa nilai estimasi koefisien jalur pengaruh langsung selfefficacy terhadap kecerdasan emosional sebesar 0,372 dengan nilai titik kritis (CR) sebesar 4,38 dan probabilitas signifikan pada tingkat kepercayaan 95\%. Hasil ini berarti terdapat cukup bukti untuk menerima hipotesis $\left(\mathrm{H}_{4}\right)$ bahwa semakin tinggi self-efficacy, maka semakin baik kecerdasan emosional. Mencermati nilai koefisien jalur bertanda positif dapat diartikan bahwa hubungan antara self-efficacy dan kecerdasan emosional adalah searah. Hubungan searah tersebut menunjukkan self-efficacy yang tinggi mampu meningkatkan kecerdasan emosional. Dengan demikian, semakin tinggi implementasi self-efficacy, maka semakin baik pula kecerdasan emosional. Hasil penelitian ini memperkuat teori yang dikemukakan oleh Pervin dan John (1997) yang mengatakan pegawai dengan self-efficacy tinggi memiliki suasana hati lebih baik, karena ia memiliki 
kemampuan untuk mengenali emosi diri, memotivasi diri sendiri, mengenali emosi orang lain, dan kemampuan membina pengaruh dengan orang lain yang disebut kecerdasan emosional. Teori Mayer dan Salovey (1990) mengatakan kecerdasan emosional merupakan suatu kemampuan individu dalam menggunakan emosinya secara efektif untuk mengelola diri sendiri dan mempengaruhi orang lain.

\section{H5: Kecerdasan emosional berpengaruh signifikan pada kinerja dokter muda.}

Hasil pengujian diperoleh bahwa nilai estimasi koefisien jalur pengaruh langsung kecerdasan emosional terhadap kinerja individu dokter muda sebesar 0,038 dengan nilai titik kritis (CR) sebesar 2,96 dan probabilitas ( $p$-value) lebih kecil dari 0,05 berarti signifikan pada tingkat kepercayaan 95\%. Hasil pengujian menunjukkan bukti realitas yang terjadi, sehingga hipotesis $\left(\mathrm{H}_{5}\right)$ yang dinyatakan kecerdasan emosional berpengaruh signifikan terhadap kinerja dokter muda dapat diterima. Namun, dengan melihat tanda koefisien jalur positif berarti hubungan antara kecerdasan emosional dan kinerja individu dokter muda searah. Hasil ini mengindikasikan bahwa semakin tinggi implementasi kecerdasan emosional, maka semakin tinggi kinerja dokter muda. Sebaliknya, jika kecerdasan emosional yang dimiliki oleh dokter muda semakin rendah, maka akan mengakibatkan semakin rendah pula tingkat kinerja dokter muda. Hasil penelitian ini mengkonfirmasi dan memperluas temuan penelitian yang dilakukan Yadav (2011) tentang kecerdasan emosional berpengaruh positif dan signifikan terhadap kinerja. Temuan dalam penelitian Yadav (2011) tersebut hasilnya sama dengan temuan penelitian yang dilakukan oleh Shahhosseini et al. (2012) dan Idrus (2016).

\section{H6: Self-efficacy berpengaruh signifikan terhadap kinerja individu dokter muda.}

Pengujian secara langsung diperoleh nilai estimasi koefisien jalur self-efficacy terhadap kinerja individu dokter muda sebesar 0,849 dengan nilai titik kritis (CR) sebesar 20,19* dan nilai probabilitas ( $p$-value) signifikan pada $\alpha=0,05$. Artinya, dukungan fakta empiris terbukti untuk menerima hipotesis $\left(\mathrm{H}_{6}\right)$ bahwa semakin baik penerapan kualitas selfefficacy, maka kinerja dokter muda diharapkan semakin meningkat. Koefisien jalur bertanda positif dapat diartikan bahwa hubungan antara kualitas self-efficacy terhadap kinerja dokter muda searah. Hubungan searah mencerminkan kualitas self-efficacy yang baik dapat meningkatkan kinerja dokter muda. Dengan demikian, semakin baik selfefficacy, maka kinerja dokter muda semakin baik. Hal ini menunjukkan bahwa semakin tinggi tingkat self-efficacy yang dimiliki oleh dokter muda, maka akan semakin tinggi tingkat kinerja yang dihasilkan oleh dokter muda. Demikian pula sebaliknya, jika semakin rendah tingkat self-efficacy yang dimilikinya, maka hal itu akan semakin rendah pula tingkat kinerja yang dihasilkan oleh dokter muda. Dengan demikian, makna yang dapat ditarik dari temuan ini adalah self-efficacy dan kinerja dokter muda merupakan dua hal yang sangat penting, mempunyai pengaruh satu dengan lainnya. Hasil temuan ini mengkonfirmasi dan memperluas teori Bandura (1986) tentang selfefficacy yang merupakan penilaian atau persepsi subyektif dari individu terhadap kemampuan dirinya dalam mengorganisir dan memutuskan tindakan yang dibutuhkan untuk mencapai kinerja (performance) yang diinginkan. Demikian pula. hasil penelitian ini mengkonfirmasi dan memperluas hasil penelitian sebelumnya yang telah dilakukan oleh Khurshid et al. (2012). Temuan dalam penelitian mereka tersebut disimpulkan bahwa terdapat pengaruh positif dan signifikan antara self-efficacy dan kinerja guru di sekolah menengah Rawalpindi dan Islamabad di India. Selain itu, mereka juga 
menemukan bahwa guru perempuan dan guru yang berpengalaman mengajar lebih lama, serta guru yang memiliki jenjang pendidikan lebih tinggi akan memiliki selfefficacy lebih tinggi.

\section{H7: Kinerja dokter muda berpengaruh tidak signifikan terhadap kepuasan dokter muda.}

Hasil pengujian pengaruh langsung kinerja dokter muda terhadap kepuasan dokter muda diperoleh nilai estimasi koefisien jalur sebesar 0,325 dengan nilai titik kritis (CR) sebesar $1,42 *$ dan nilai probabilitas ( $p$-value) lebih besar dari $\alpha=0,05$. Hasil pengujian menunjukkan tidak dapat membuktikan secara realitas untuk menerima hipotesis $\left(\mathrm{H}_{7}\right)$ yang dinyatakan bahwa kinerja dokter muda berpengaruh signifikan terhadap kepuasan kerja dokter muda. Namun, dengan melihat tanda koefisien jalur positif, berarti hubungan antara kinerja individu dokter muda dan kepuasan dokter muda searah. Hasil ini mengindikasikan bahwa semakin tinggi implementasi kinerja individu dokter muda, maka semakin tinggi kepuasan kerja dokter muda, meskipun hubungan searah tersebut tidak signifikan. Hasil penelitian ini berbeda dengan penelitian yang disampaikan oleh Riketta (2002) dan Laschinger et al. (2001) yang berpendapat bahwa kepuasan kerja sebagai salah satu penentu utama dari kinerja, baik individu maupun organisasi. Hal itu juga mengkonfirmasi dan memperluas teori kepuasan kerja yang dikemukakan oleh Smith (1996) tentang dampak dari kepuasan kerja terhadap kinerja akan dapat meningkatkan produktivitas kerja. Kinerja dokter muda berpengaruh tidak signifikan terhadap kepuasan kerja. Kinerja dokter muda bagus, tidak menjadi jaminan bahwa dokter muda tersebut pasti lulus menjadi dokter, karena dokter muda masih harus mengikuti ujian kompetensi dokter. Apabila dokter muda lulus dalam ujian kompetensi dokter, maka dokter muda tersebut akan dikukuhkan menjadi dokter, sehingga dokter muda akan merasa puas setelah lulus ujian kompetensi dokter.

\section{KESIMPULAN}

Hasil penelitian ini menemukan bahwa: (1) Burnout berpengaruh secara signifikan terhadap kecerdasan emosional. Temuan penelitian ini mendukung hasil penelitian sebelumnya yang telah dilakukan oleh Alam (2010); Devi (2011); Khanifar et al. (2012); Thomas, et al. (2012); dan Idrus (2016); (2) Burnout berpengaruh signifikan terhadap kinerja dokter muda. Temuan ini memperluas hasil penelitian sebelumnya yang dilakukan oleh Babakus et al. (2009), Ybema, Smulders, dan Bongers (2010); Gorji (2011), Gorji dan Vaziri (2011), Kounenou dan Demerouti (2012), Ybema, Smulders, dan Bongers (2010); dan Chen dan Kao (2012). Namun, penelitian ini berbeda dengan penelitian yang dilakukan oleh Idrus (2016); (3) Burnout berpengaruh tidak signifikan terhadap self-efficacy. Temuan penelitian ini berbeda juga dengan temuan penelitian yang telah dilakukan sebelumnya oleh Skaalvik dan Skaalvik (2010); Maharani (2011); Aftab et al. (2012); dan Idrus (2016); (4) Self-efficacy berpengaruh signifikan pada kecerdasan emosional. Temuan penelitian ini memperkuat teori yang dikemukakan oleh Pervin dan John (1997) yang mengatakan individu dengan selfefficacy tinggi memiliki suasana hati lebih baik, karena ia memiliki kemampuan untuk mengenali emosi diri, memotivasi diri sendiri, mengenali emosi orang lain, dan kemampuan membina pengaruh dengan orang lain yang disebut kecerdasan emosional; (5) Kecerdasan emosional berpengaruh signifikan pada kinerja individu dokter muda, temuan ini memperluas hasil penelitian Yadav (2011). Hasilnya sama dengan temuan 
penelitian yang dilakukan oleh Shahhosseini et al. (2012) dan Idrus (2016); (6) Selfefficacy berpengaruh signifikan pada kinerja dokter muda. Temuan penelitian ini memperluas teori Bandura (1986) tentang self-efficacy merupakan penilaian atau persepsi subyektif dari seseorang terhadap kemampuan dirinya dalam mengorganisir dan memutuskan tindakan yang dibutuhkan untuk mencapai kinerja (performance) yang diinginkan; (7) Kinerja dokter muda berpengaruh tidak signifikan terhadap kepuasan dokter muda. Temuan penelitian ini berbeda dengan penelitian yang dilakukan oleh Riketta (2002) dan Laschinger et al. (2001) yang berpendapat bahwa kepuasan kerja sebagai salah satu penentu utama dari kinerja, baik individu maupun organisasi. Kinerja dokter muda yang bagus tidak menjadi jaminan bahwa dokter muda tersebut pasti lulus menjadi dokter, karena ia masih harus mengikuti ujian kompetensi dokter. Apabila dokter muda lulus dalam ujian kompetensi dokter, maka ia akan dikukuhkan menjadi dokter, sehingga ia akan merasa puas setelah lulus ujian kompetensi dokter.

\section{DAFTAR REFERENSI}

Aftab, N., Ali, S. A., \& Mehmood, R. (2012). Relationship of Self-Efficacy and Burnout Among Physicians. Academic Research International Vol 2 No 2, 539548.

Alam, R. (2007). Empowerment hubungannya dengan burnout paramedis rumah sakit rujukan. Disertasi. Tidak dipublikasikan.

Alam, R. (2010). Pengaruh PemberdayaanTerhadap Kelelahan Kerja dan Kecerdasan Emosional Perawat dan Bidan Pada Rumah Sakit Umum Rujukan di Sulawesi Selatan. Jurnal EKUITAS, pp. 187-209.

Dewanto, A.M. \& Nurhayati, S. (2013). Pengaruh Kecerdasan Emosional dan Kecerdasan Spiritual terhadap Sikap Etis dan Prestasi Mahasiswa Akuntansi (Studi Pada Perguruan Tinggi di Kota Pekalongan). http://journal.unikal.ac.id/index.php/lppm/ article/viewFile/139/76.

Muttaqiyathun, A. (2010). Hubungan Emotional Quotient, Intelectual Quotient, dan Spiritual Quotient dengan Entrepreneur's Performance, Jurnal Manajemen Bisnis, Vol 2 No 3 (Maret) 221-234.

Babakus, E., Yavas, U., \& Ashill, N. J. (2009). The role of customer orientation as a moderator of the job demandebumoute performance relationship: a surface level trait perspective. Journal of Retailing, Vol 85, 480-492.

Bandura, A. (1997). Self-Efficacy:The Exercise of Control. New York: W.H. Freeman.

Bandura, A. (1986). Social Foundation of Thought and Action: A Social Cognitive Theory. New Jersey: Prentice-Hall, Inc.

Baron, R. A. \& Byrne, D. (1991). Social Psychology Understanding Human Interaction. Boston: Allyn \& Bacon.

Baron, R. A. \& Greenberg, J. (2008). Behaviour in organization: understanding and managing the human side of work. 9th edition. USA: Prentice-Hall, Inc.

Bhanugopan, R. \& Alan, F. (2006). An Empirical Investigation of Job Burnout among Expatriates. Personal Review Vol 35 No 4, 449-468.

Chen, C. F. \& Kao, Y. L. (2012). Investigating The Antecedents and Concequences of Burnout and Isolation Among Flight Attendants. Tourism Management Vol 3 
pp.863-874.

Devi, M. (2011). Burnout In Relation to Emotional Intelligence of Regular and Special School Teachers. Indian Streams Research Journal, Vol 1 No.6, 48-53.

Gibson, J. L., Ivancevich, J. M., \& Donnelly (2010). Organisation: Behavior, Structure, Process. Nunuk Ardiarni (Penerjemah). (2010). Organisasi: Perilaku, Struktur dan Proses. Alih Bahasa. Jilid 1. Jakarta: Binarupa Aksara.

Golemen, Boyatzis, \& McKee (2002). Primal Leadership: Learning To Lead With Emotional Intelligence. Printed in the United States of America.

Gorji, M. (2011). The Effect of Job Burnout Dimension on Employees Performance. International Journal of Social Science and Humanit, 1 (4) 243-224.

Gorji, M. \& Vaziri, S. (2011). The Survey Job Burnout Status and Its Relation With The Performance of The Employees (Case Study: Bank). International Conference on Innovation, Management, and Service Vol 14, 219-224.

Idrus, S. (2016), Pengaruh Pemberdayaan Psikologis Terhadap self-Efficacy, Burnout, Kecerdasan Emosional, Kepuasan kerja Dan Kinerja Individu: Studi Terhadap Pramuwisata Di Provinsi Nusa Tenggara Barat. Disertasi. Fakultas Ilmu Administrasi Universitas Brawijaya, Malang.

Imaniar, R. R. L. \& Sularso, R. A. (2016). Pengaruh Burnout Terhadap Kecerdasan Emosional, Self-Efficacy, dan Kinerja Dokter Muda di Rumah Sakit dr. Soebandi. Jurnal Maksipreneur: Manajemen, Koperasi, dan Entrepreneurship, Vol 5 No 2 (Juni) 46-56.

lvancevich, J. M., Konopaske, R., Matteson, M. T. (2006). Perilaku dan Manajemen Organisasi. Edisi 7. Jilid 1. Jakarta: Penerbit Erlangga.

Jorfi, H., Jorfi, S., \& Moghadam, K. (2010). Impact of Emotional Intelligence on Performance of Employees. Postmodern Openings, Vol 1 No 4, 63-74.

Kaiser, S. \& Ringlstetter, M. J. (2011). Strategic Management of Professional Service Firms: Theory and Practice. Berlin: Springer-Verlag.

Khanifar, H., Maleki, H., Nazari, K., \& Emami, M., (2012). The Study of The Relation Between Emotional Intelligence and Burnout of Staff (Case Study of Staff at State Universities in India). Interdisciplinary Journal of Contemporary Research in Business, Vol 3 No 10, 204-223.

Kounenou, G. \& Demerouti (2012). Job Burnout and Employees Performance. Advance Research in Economic and Management Sciences. Vol 2, 35-42.

Khurshid, F., Qasmi, F. N., \& Ashraf, N. (2012). The Relationship Between Teachers Self-Efficacy and Their Perceived Job Performance. Interdisciplinary Journal of Contemporary Research in Business, Vol 3 No 10, 204-223.

Laschinger, H. K. S., Wong, C., \& Greco, P. (2006). The impact of staff nurse empowerment on person job fit and work engagement/bournout. Nursing Administration Quarterly, Vol 30, 358-367.

Lev, S. \& Koslowsky M. (2009). Moderating the collective and self-efficacy relationship. Journal of Educational Administration 7 (4) 452-462.

Levy, P. L. (2003). Industrial/Organizational Psychology: Understanding the workplace. Boston: Houghton Miflin Company. 
Luthans, F. (2006). Organization Behavior. 10th edition. Singapore: McGraw-Hill Book Co.

Maharani. D. R. (2011). Pengaruh Self-Efficacy terhadap Burnout pada Guru di Kota Bogor. Jurnal Psikologi Universitas Gajahmada Vol 1, 1-10.

Maslach, C. \& Jackson, S. E. (1981). The measurement of experienced burnout. Journal Occupational Behavior, Vol 2, 99-113.

Mayer, J. D. \& Salovery, P. (1990). Emotional Intelligence. Imagination, Cognition, and Personality Vol 9 No 3, 185-211.

Mathis, R. L. \& Jackson, J. H. (2009). Manajemen Sumber Daya Manusia. Jakarta: Salemba Empat.

Patton, P. (2011). EQ Karir Sukses. (Penerjemah: Zaini Dahlan). Jakarta: Pustaka Delaprata.

Pervin, L. \& John, O. (1997). Personality: Theory and research. 7th Edition. New York: John Wiley \& Sons, Inc.

Pines, A. \& Guendlman, S. (1995). Exploring the Relevance of Burnout to Mexican Blue Collar Woman. Journal of Vovational Behavior Vol 47, 1-20.

Riketta, M. (2002). Attitudinal Organizational commitment and job performance: a meta-analysis. Journal of Organizational Behavior, Vol 23 No 3, 257-266.

Sam'ani (2008). Penerapan Emotional Spiritual Quotient (ESQ) Untuk Meningkatkan Kinerja Karyawan. Jurnal Pengembangan Humaniora Vol 8 No 1 (April).

Schaufeli, W. \& Buunk, B. P. (2003). Burnout: An overview of 25 years of research and theorizing. In M. J. Schabracq, J. A. M. Winnubst, \& C. L. Cooper (Eds.). Handbook of work and health psychology. p. 338-425.

Shahhosseini, M., Silong, A.D., Ismail, I. A., \& Uli, J. (2012). The Role of Emotional Intelligence on Job Performance. International Journal of Business and Social Science Vol 3 No 21, 241-246.

Skaalvik, E. M., \& Skaalvik, S. (2010). Teacher self-efficacy and teacher burnout: A study of relations. Teaching and Teacher Education, Vol 26 No 1, 1059-1069.

Smith, J. (2000). Empowering People. London: Kogan Page.

Thomas, N. S., Mousavy, S., Mukundan, J., \& Nimehchisalem, V. (2012). The Relationship Between Burnout and Trait Emotional Intelligence Among Secondary School Teachers in Malaysia. International Journal of Applied Linguistics \& English Literature 1(4), 15-23.

Maharani, V. (2013). Pengaruh Burnout Dan Kecerdasan Emosional Terhadap Kinerja Pegawai PT Bank Mega Syari'ah Cabang Malang. Jurusan Manajemen Fakultas Ekonomi UIN Maulana Malik Ibrahim Malang.

Ybema, J. F., Smulders, P. G. W., Bongers, P. M. (2010). Antecendents and Consequences of Employee Absenteeism: a Longitudinal Perspective on the Role of Job Satisfaction and Burnout. European Journal of Work and Organizational Psychology, Vol 19, 102-124.

Yadav, N. (2011). Emotional Intelligence and its Effects on Job Performance: A Comparative Studi on life Insurance Sales Professionals. International Journal of Service Industry Management, Vol 17, 258-270. 